\title{
Molecular characterisation of radish cultivars ${ }^{1}$
}

\author{
Caracterização molecular de cultivares de nabo-forrageiro
}

\author{
Sara Michelly Cruz ${ }^{2 *}$, Marcela Carlota Nery ${ }^{2}$, Édila Vilela de Resende Von Pinho ${ }^{3}$ e Marcelo Luiz de Laia ${ }^{4}$
}

\begin{abstract}
The radish has been gaining importance in the Brazilian market due to its use as a green manure and cover crop, and also due to its potential for the production of biodiesel, however there are only two registered cultivars, which are morphologically very similar. Determination of genetic purity is a prerequisite in marketing seeds as it ensures uniformity of the crop and is important in breeding programs. The aim of this work therefore was to evaluate the similarity and genotype patterns which permit differentiation of the commercial radish cultivars IPR 116 and CATI AL-1000. In order to do this, isoenzyme electrophoretic patterns were analysed in dry seeds, soaked seeds, seedling leaves and young leaves; the isoenzymes used being: superoxide dismutase, catalase, esterase, glutamate-oxalocetate, malate dehydrogenase and isocitrate lyase. Thirtyseven RAPD primers and 10 ISSR primers in leaves of the CATI AL-1000 and IPR-116 cultivars were analysed. Among the isoenzymes under study, the most polymorphic were glutamate oxalocetate, malate dehydrogenase, esterase and superoxide dismutase, with the superoxide dismutase system giving the best characterisation for all stages of development. The catalase isoenzyme system did not make it possible to differentiate between cultivars at any stage of development, and isocitrate lyase was not revealed by the protocol used. In analysis of the markers, 27 RAPD primers and eight ISSR primers showed polymorphism. The results indicate that it is possible to determine reliable descriptors based on isoenzymes at different stages of development of the radish and with the use of RAPD and ISSR primers.
\end{abstract}

Key words: Raphanus sativus. ISSR. RAPD. Isoenzymes. Stage of development.

RESUMO - O nabo-forrageiro tem ganhado importância no mercado brasileiro como adubo verde, planta de cobertura e pelo potencial para produção de biodiesel, no entanto estão registradas apenas duas cultivares que são morfologicamente muito semelhantes. A determinação da pureza genética é um dos requisitos para comercialização de sementes, pois garante a uniformidade de plantio, e é importante para os programas de melhoramento. Por tanto, objetivou-se com este trabalho avaliar a similaridade e padrões genotípicos que permitam diferenciar as cultivares comerciais de nabo-forrageiro 'IPR 116' e 'CATI AL-1000'. Para isso, foi analisado o padrão eletroforético de isoenzimas em sementes secas, sementes embebidas, folhas de plântulas e folhas jovens. As isoenzimas usadas foram: superóxido dismutase, catalase, esterase, glutamato - oxilacetato, malato desidrogenase e isocitrato liase. Foram analisados 37 primers RAPD e 10 primers ISSR em folhas das cultivares 'CATI AL-1000' e 'IPR-116'. Entre as isoenzimas estudadas, as mais polimórficas foram glutamato - oxilacetato, malato desidrogenase, esterase e superóxido dismutase, tendo o sistema superóxido dismutase realizado a melhor caracterização para todos os estádios de desenvolvimento. O sistema isoenzimático catalase não permitiu distinguir as cultivares em nenhum estádio de desenvolvimento e a isocitrato liase não revelou com o protocolo utilizado. Na análise dos marcadores 27 primers RAPD e oito primers ISSR apresentaram polimorfismo. Os resultados indicam que há possibilidade de determinar descritores confiáveis com base em isoenzimas em diferentes estádios de desenvolvimento de nabo-forrageiro e com uso de primers RAPD e ISSR.

Palavras-chave: Raphanus sativus. ISSR. RAPD. Isoenzimas. Estádio de desenvolvimento.

\footnotetext{
*Autor correspondência

Recebido para publicação em 26/11/2013; aprovado em 26/06/2014

Pesquisa financiada pela Fapemig

${ }^{2}$ Departamento de Agronomia, Universidade Federal dos Vales do Jequitinhonha e Mucuri, Rodovia MGT 367, Km 583, n 5000, Alto da Jacuba, Diamantina-MG, Brasil, 39.100-000, saramichellycruz@gmail.com, nery.marcela@gmail.com

${ }^{3}$ Departamento de Agricultura, Universidade Federal de Lavras, Campus Universitário, Caixa Postal 3037, Lavras-MG, Brasil, 37.200-000, edila@ dag.ufla.br ${ }^{4}$ Departamento de Engenharia Florestal, Universidade Federal dos Vales do Jequitinhonha e Mucuri, Rodovia MGT 367, Km 583, n ${ }^{\circ} 5000$, Alto da Jacuba, Diamantina-MG, Brasil, 39.100-000, marcelolaia@gmail.com
} 


\section{INTRODUCTION}

The radish (Raphanus sativus L. var. oleiferus Metzg), known locally as nabo-forrageiro, belongs to the Brassicaceae family. It is a plant with a winter annual cycle, hardy (CRUSCIOL et al., 2005), allogamous and diploid (SHIRASAWA et al., 2011), and is easy to cross with plants of the genus Raphanus (DERPSCH; CALEGARI, 1992). The plant has been used in crop rotation and as green manure (CRUSCIOL et al., 2005). Its seeds contain oil with the potential for biodiesel production, and the byproducts of extraction can be used for animal feed (ABDALLA et al., 2008; SOUZA et al., 2009).

The cultivars CATI AL-1000 and IRP 116 are registered in the Brazilian market. They are morphologically very similar, which makes the work of identification and characterisation difficult. Definition in characterising cultivars is important because genetic purity is a requirement when marketing seeds; it ensures uniformity of the crop and in the expression of developed features, and is also important in breeding programs.

The International Seed Testing Association (ISTA) considers morphological, physiological, cytological and biochemical characteristics as descriptors for the certification of genetic purity (INTERNATIONAL SEED TESTING ASSOCIATION, 1996). In most cases in Brazil morphological descriptors are used. But this is a limited process, one which is time consuming and that cannot be carried out at simply any period in the plant cycle; different methods are therefore necessary.

One method used is that of molecular markers, which allow genetic diversity to be evaluated through biochemical means and/or directly from the DNA. The detection of isoenzymes was the first method of genetic analysis that was developed (BYRNE; LITTLETON, 1988). Isoenzymes were considered efficient in differentiating individuals of the same species and cultivar, such as the soybean (VIEIRA et al., 2009) and red palm (MARTINS et al., 2007). However, this marker is influenced by the environment, the phenological stage and the presence of pathogens (ALFENAS et al., 2006).

Techniques were later employed to evaluate DNA directly based on the Polymerase Chain Reaction (PCR), such as Random Amplified Polymorphic DNA (RAPD) and Inter Single Sequence Repeats (ISSR), which do not suffer from environmental influences nor from the stage of development of the organism being analysed (BORÉM; MIRANDA, 2013). The main advantage of RAPD and ISSR markers is that they are produced from arbitrary sequences, which allows the analysis of any species without it having been described genetically. These techniques moreover, require only a small amount of DNA and are of relatively low cost (TRIPATHI et al., 2012).
In situations where morphological characteristics may lead to discussion, DNA-based markers have been used with great success. The use of RAPD markers has been efficient in differentiating Rapahnus sativus from other brassicae (MOHAMED, 2009) and from other species of the same genus (PRADHAN; YANG; PLUMMER, 2004; RABBANI et al., 1998) in the identification and analysis of genetic diversity in broccoli (Brassica oleracea L), cauliflower (Brassica oleracea L. var. botrytis) and rice (Oryza sativa $\mathrm{L}$ ) (ASTARINI et al., 2004; HU; QUIROS, 1991; PERVAIZ et al., 2010). The techniques of RAPD and ISSR were successfully used jointly to differentiate species of the genus Raphanus (LIU et al., 2007) and varieties of radish (MUMINOVIĆ et al., 2005), and to identify variations within cultivars of the pistachio (Pistacia vera $\mathrm{L}$ ) (TAGIZAD et al., 2010).

Given the above, the aim was to evaluate the similarity and genotype patterns that allow differentiation of radish cultivars through the use of isoenzyme electrophoresis and RAPD and ISSR molecular markers.

\section{MATERIAL AND METHODS}

The experiments were carried out at the Central Seed Laboratory of the Department of Agriculture at the Federal University in Lavras, in the state of Minas Gerais (MG). Seeds of the CATI AL-1000 and IPR 116 cultivars were used from the crop of 2011, respectively donated by the Coordenadoria de Assistência Técnica Integral of the state of São Paulo (CATI) and the Agronomic Institute of Paraná (IAPAR).

The physiological quality of the radish seeds was evaluated by the tests for first germination count and germination (NERY; CARVALHO; FRAGA, 2009) and the speed of germination index (MAGUIRE, 1962) with four replications of 50 seeds for each cultivar in each test. The tests were statistically evaluated in a completely randomised design (CRD) with the averages obtained being subjected to variance analysis by F-test at $5 \%$ probability using the Sisvar software (FERREIRA, 2000).

Enzyme extraction was carried out on dried seeds, seeds soaked in water for 12 hours, cotyledon leaves obtained two days after sowing, and a second pair of leaves obtained at 15 days. Two replications of 100 seeds were sown in a soil and sand substrate $(2: 1)$ in plastic trays and placed in a temperature-controlled environment at $25^{\circ} \mathrm{C}$ until reaching the stages described.

Each of the plant materials: dry seeds, seeds soaked in water for 12 hours, cotyledons obtained two days after sowing and a second pair of leaves obtained after 15 days, were manually macerated with a PVP antioxidant (polyvinylpyrrolidone) and liquid nitrogen in a mortar, and stored at a temperature of $-86^{\circ} \mathrm{C}$. To $100 \mathrm{mg}$ subsamples 
were added $300 \mu \mathrm{L}$ of Tris $\mathrm{HCl}, 0.2 \mathrm{M}, \mathrm{pH} 8.0$ extraction buffer. The material was stored in a refrigerator for 12 hours and then centrifuged at $14,000 \mathrm{rpm}$ for 30 minutes at $4{ }^{\circ} \mathrm{C}$. For the electrophoretic run, $50 \mu \mathrm{L}$ of the supernatant was applied to the gel channels, the run being held in a discontinuous polyacrylamide gel system, a tris-glycine gel/electrode system, a pH of 8.9 , at $4{ }^{\circ} \mathrm{C}$ and $150 \mathrm{~V}$ for 5 hours. At the end of the run, the gels were processed for the enzymes esterase, superoxide dismutase, catalase, malate dehydrogenase and alcohol dehydrogenase following the protocols of Alfenas et al. (2006) and Scandalios (1969).

Extraction of the genomic DNA was performed on the first pair of leaves from both cultivars. For this the seeds were planted in a soil and sand substrate $(2: 1)$ in plastic trays and placed in a temperaturecontrolled environment at $25^{\circ} \mathrm{C}$. DNA was isolated by the 2\% CTAB method (DOYLE; DOYLE, 1990). The DNA was quantified and the quality evaluated with a NanoDrop ND1000 spectrophotometer.

The RAPD marker amplification reaction was performed in $18.55 \mu \mathrm{L}$ of: $13.4 \mu \mathrm{L}$ ultra pure water, $2.5 \mathrm{mM}$ of each dNTP, $1.25 \mu \mathrm{L}$ buffer, $0.65 \mu \mathrm{L}$ Taq DNA polymerase units, $0.75 \mu \mathrm{L}$ primer and $30 \mathrm{ng}$ genomic DNA. Amplification took place in an Axygen II Maxygene automatic DNA amplification thermocycler, programmed for one cycle at $94{ }^{\circ} \mathrm{C}$ for two minutes, 40 cycles at $94{ }^{\circ} \mathrm{C}$ for 40 seconds, $36{ }^{\circ} \mathrm{C}$ for 1 minute 30 seconds, $72{ }^{\circ} \mathrm{C}$ for 1 minute 30 seconds, and one cycle of $72{ }^{\circ} \mathrm{C}$ for five minutes. Initiator oligonucleotides were used from the following primer sets: OPK $(04,10,14,17)$, OPL (04, $05,07,15,18,19)$, OPM $(04,06,07,09,15,19)$, OPN $(01,05,12,16,18,19)$, OPO $(05,06,12,15,19,20)$ and $\mathrm{S}(25,27,31,36,38,297,300,333,499)$, which have been tested for the genus Raphanus (KONG et al., 2011; LIU et al., 2007) and were produced by Labscience Sigma-Aldrich.

The ISSR marker amplification reaction was carried out in $12 \mu \mathrm{L}$ of: $5.15 \mu \mathrm{L}$ ultra pure water, $2.5 \mathrm{mM}$ of each $\mathrm{dNTP}, 1.0 \mu \mathrm{L}$ buffer solution, $0.55 \mu \mathrm{L}$ primer, $0.6 \mu \mathrm{LTaq}$ DNA polymerase units and $30 \mathrm{ng}$ genomic DNA. Amplification took place in an Axygen II Maxygene automatic DNA amplification thermocycler, programmed for one cycle at $94{ }^{\circ} \mathrm{C}$ for 5 minutes, 35 cycles at $94{ }^{\circ} \mathrm{C}$ for 20 seconds, $43{ }^{\circ} \mathrm{C}$ for 20 seconds, $72{ }^{\circ} \mathrm{C}$ for 20 seconds and one cycle of $72{ }^{\circ} \mathrm{C}$ for five minutes. Initiator oligonucleotides were used from the UBC random primer set $(808,810,812,820,827,834,848,851$, $858,878)$ produced by Labscience Sigma-Aldrich.

The amplification products were separated by electrophoresis at 100 volts for 90 minutes on polyacrylamide gel. For development, the gels were stained in a silver nitrate solution (SANGUINETTI; DIAS NETO; SIMPSON, 1994).
The gels were analysed manually using a binary system where the bands were marked with ' 1 ' if present and ' 0 ' if absent. Unstable bands (poorly-defined or diffuse) were not considered and only the consistent bands (sharply-defined and appearing in all gels) were studied. Genetic similarity was estimated by the Jaccard similarity coefficient, obtained with the help of the NTSYS-pc 2.1e software (ROHLF, 2000).

\section{RESULTS AND DISCUSSION}

From evaluation of the physiological quality of the batches (Table 1) it was seen that there were no statistical differences between them, suggesting that changes in isoenzyme patterns are exclusively genetic in origin. Studies show that the activity of isoenzymes is influenced by the physiological quality of the seeds and tissue and the stage of development being studied (FERREIRA; GRATTAPAGLIA, 1998). Analysis of isoenzyme profiles show variations in the intensity and number of bands as a function of the plant material used. To differentiate the cultivars, differences in the number and position of the sharply-defined bands were considered.

Profiles of the isoenzyme catalase did not make it possible to distinguish between cultivars, and isocitrate lyase was not revealed using the methodology under test.

For dry seeds, the isoenzyme glutamate oxaloacetate (GOT) displayed three bands for cultivar RPI 116 and two for CATI AL-1000 (Figure 1). The soaked seeds of cultivar CATI AL-1000 displayed no bands, whereas for IPR 116, three bands were detected. There was a difference in the position of the bands in the seedlings. In the young leaves on the other hand, the bands were not sharply-defined and it was not possible to differentiate them. Differences in the banding pattern of this isoenzyme were also seen in rice seeds during the germination

Table 1 - Results for germination (G), first germination count (FC) and speed of germination index (SGI), obtained from two batches of radish seeds (Raphanus sativus L. var. oleiferus Metzg) from the CATIs AL-1000 and IPR 116 cultivars

\begin{tabular}{lrcc}
\hline \multicolumn{1}{c}{ Batch } & G $(\%)$ & FC $(\%)$ & \multicolumn{1}{c}{ SGI } \\
\hline CATI AL AL1000 & $89 \mathrm{~A}$ & $83 \mathrm{~A}$ & $20.92 \mathrm{~A}$ \\
IPR 116 & $90 \mathrm{~A}$ & $89 \mathrm{~A}$ & $22.37 \mathrm{~A}$ \\
CV $(\%)$ & 6.83 & 9.37 & 7.90 \\
F & 0.013 & 1.508 & 1.443 \\
Pr $>$ Fc & 0.9114 & 0.265 & 0.275 \\
\hline
\end{tabular}

Averages followed by the same letter in a column do not differ by F-teste at $5 \%$ probability 
Figure 1 - Electrophoretic profile of the glutamate oxilacetato isoenzyme system (GOT) in cultivars IPR 116 and CATI AL-1000 of the radish (Raphanus sativus L. var. oleiferus Metzg), at different stages of development: dry seed (DS), soaked seed (S), seedling leaf (SL), young leaf (YL)

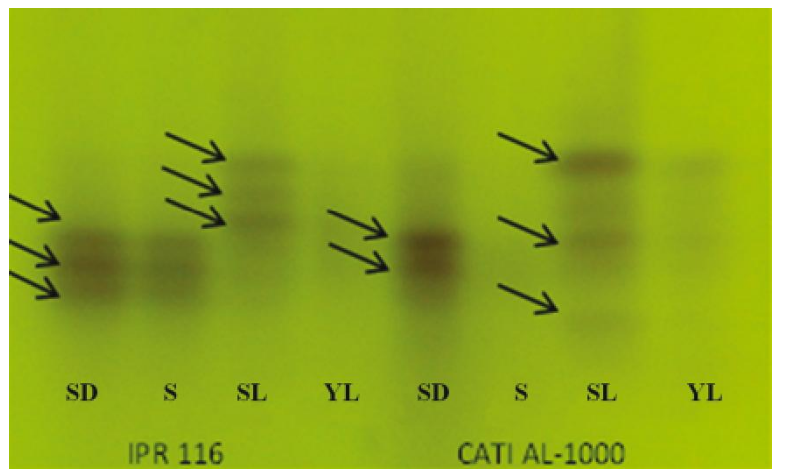

process, however they occurred in the same way in different ecotypes of red rice (MALONE et al., 2007).

The isoenzyme malate dehydrogenase (MDH) displayed low polymorphism (Figure 2). The dried and soaked seeds had a similar banding pattern. In the leaves from the seedlings, it was possible to differentiate where there were two bands in cultivar IPR 116 and three in CATI AL-1000; and where, in the young leaf, a band was only displayed for cultivar IPR 116 (Figure 2). In a study with aged seeds, MDH did not make it possible to distinguish between cultivars of cotton (MENEZES et al., 2008). In an analysis of leaves and pollen in the nectarine, the $\mathrm{MDH}$ profiles were the most polymorphic among the isoenzymes tested by Lima et al. (2003).

Figure 2 - Electrophoretic profile of the malate dehydrogenase isoenzyme system in cultivars IPR 116 and CATI AL-1000 of the radish (Raphanus sativus L. var. oleiferus Metzg), at different stages of development: dry seed (DS), soaked seed $(\mathrm{S})$, seedling leaf (SL), young leaf (YL)

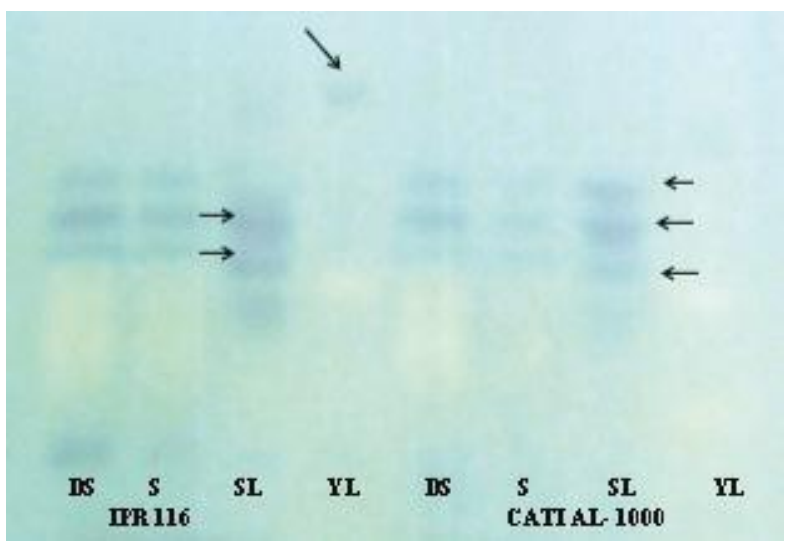

For the isoenzyme esterase (EST) (Figure 3), dry seeds of the CATI AL-1000 and IPR 116 cultivars, presented the same number of sharply-defined bands, differing in the position of the first band. In the soaked seeds, the cultivar IPR 116 displayed four bands and CATI AL-1000 two bands. In the leaves from the seedlings, IPR 116 showed three bands and CATI AL-1000 five. In young leaves from a plant at 10 days, there were no differences, all showing two bands. This wide variation between cultivars and stages of development can be explained by the fact that the esterases are the most polymorphic isoenzyme group in plants (WEEDEN; WENDEL, 1990); it can therefore be thought of as efficient for distinguishing radish seeds in the early stages of development. Vieira et al. (2009) also considered that esterase may help in the characterisation of soybean cultivars by making it possible to separate the cultivars into groups when extracted from dry seeds. Ferreira et al. (2009), working with gladiolus (Gladiolus sp.), were able to distinguish 11 cultivars using the third leaf for extraction of the esterase.

Figure 3 - Electrophoretic profile of the esterase isoenzyme system in cultivars IPR 116 and CATI AL-1000 of the radish (Raphanus sativus L. var. oleiferus Metzg), at different stages of development: dry seed (DS), soaked seed (S), seedling leaf (SL), young leaf (YL)

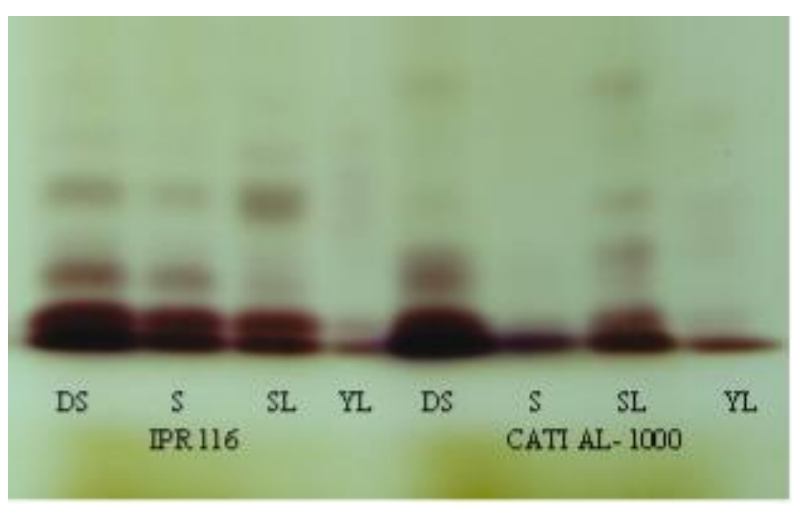

Patterns for the superoxide dismutase isoenzymes (SOD) (Figure 4) were similar at all the stages of plant development under study, presenting a different number of bands among cultivars but with the same pattern: one band in cultivar IPR 116 and three bands in cultivar CATI AL-1000. Specific patterns for SOD were also found in the soybean when comparing cultivars from both deteriorated and non-deteriorated seeds (MENEZES et al., 2008). This can be considered a good marker for distinguishing these radish cultivars, due to polymorphism among cultivars and stability at different phenological stages. 
Figure 4 - Electrophoretic profile of the superoxide dismutase system in cultivars IPR 116 and CATI AL-1000 of the radish (Raphanus sativus L. var. oleiferus Metzg), at different stages of development: dry seed (DS), soaked seed (S), seedling leaf (SL), young leaf (YL)

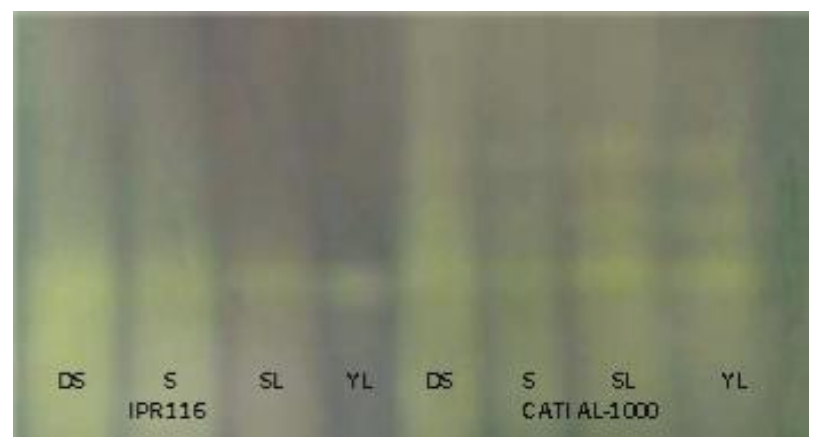

With the RAPD markers (Figure 5), eight displayed no polymorphism and two no amplification. A total of 224 bands were observed, of which 66 (29.5\%) were polymorphic (Table 2). The number of amplified bands varied from 1 to 14, with an average of 6 amplified and 2 polymorphic bands. A similar result to those found by Kong et al. (2011) in a study into varieties of the species Raphanus sativus, where the polymorphic bands varied from 2 to 13 , with an average of 6 , and $66.1 \%$ polymorphism; in the present work however the two cultivars displayed a greater number of bands, as 109 bands were obtained by Kong et al. (2011). The similarity index was 0.71 . These results indicate a great genetic diversity among Brazilian cultivars which can be explained by the high polymorphism found in both the species and the crop. In a study with RAPD in radish populations, $82 \%$ polymorphism was detected (MADHOU et al., 2005), $78.2 \%$ in the germplasm bank of Pakistan (RABBANI et al., 1998) and $85.4 \%$ between the radish cultivars (LIU et al., 2008).

Eight primers showed greater polymorphism: OPL-19, OPM-09, OPO-12, OPO-15, OPO -20, S-27, S-3 and S-300 and may be used together to identify genetic contamination in seed batches. $\mathrm{Hu}$ and Quiros (1991) identified fourteen broccoli and twelve cauliflower cultivars using four RAPD primers, and stated that two or three primers are enough to differentiate between each of the cultivars studied. Liu et al. (2008), studying 35 radish cultivars found it possible to distinguish them with five sets of three primers.

Of the 10 ISSR primers used, eight displayed polymorphism (Table 3 ). The polymorphic oligonucleotides generated 65 amplification products. Of this total, 36 bands (53.4\%) were polymorphic. The number of amplified bands varied from 1 to 12, having on average 7 bands and 4 polymorphic bands. Some of the amplified products are shown in Figure 6. Using 22 ISSR primers to distinguish 35
Figure 5 - Result of amplification with RAPD primers, for the sequence S31, OPM 07, OPO 20, OPN 16, OPK 14, OPK17, OPL 07, OPL 05, OPK 04, in cultivars CATI AL-100 (C) and IPR 116 (I) of the radish (Raphanus sativus L. var. oleiferus Metzg). Marker (M) $=1 \mathrm{Kbps}$

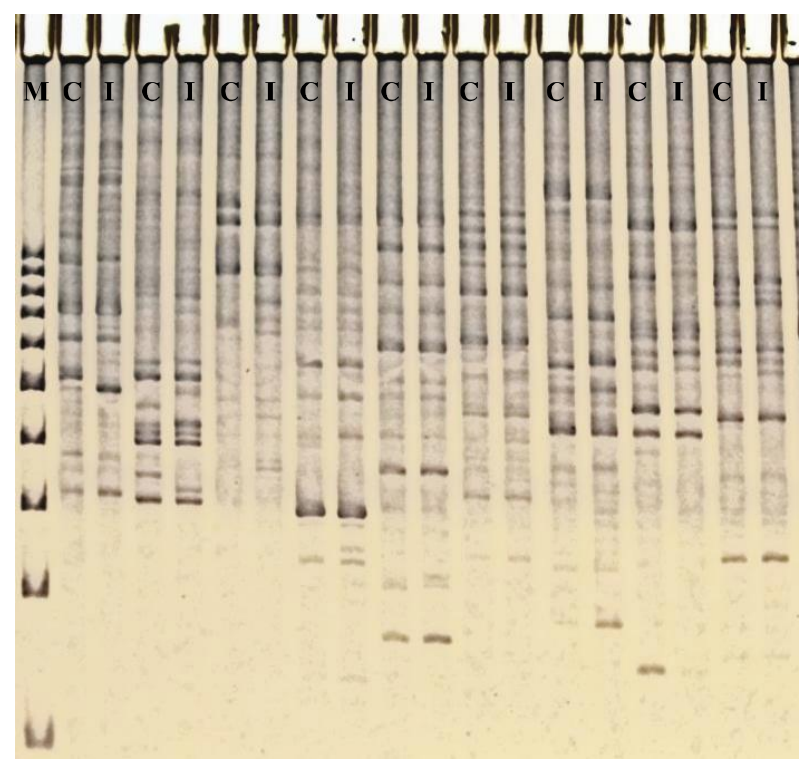

Figure 6 - Result of amplification with ISSR primers, for the sequence $808,810,812,820,827,834,848$ in cultivars RPI 116 (I) and CATI AL-1000 (C) of the radish (Raphanus sativus L. var. oleiferus Metzg). Marker (M) $1 \mathrm{Kbps}$

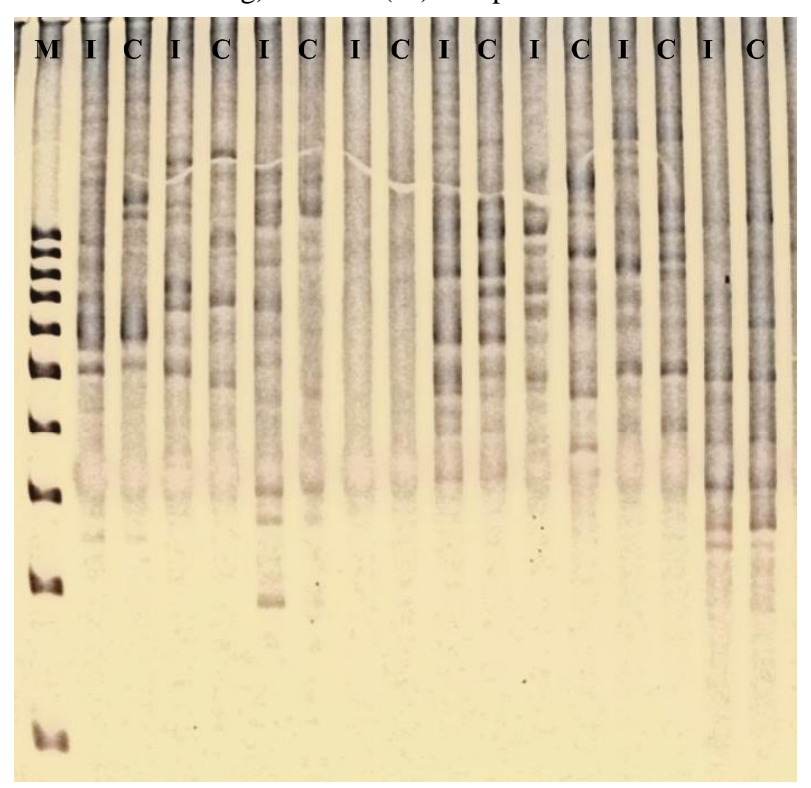

cultivars, Liu et al. (2008) obtained 250 bands, with $85.2 \%$ polymorphism, an average of 7 polymorphic bands per primer. They considered that the minimum number of primers 
needed to distinguish the 35 radish cultivars would be three groups of three primers. The most polymorphic primers for both cultivars in this study were UBC 808,
UBC 810, UBC 827, UBC 834 and UBC 858, which only amplified for one cultivar and can be used to differentiate between cultivars.

Table 2 - Ratio of the number of amplified RAPD products for each oligonucleotide, with their respective numbers of polymorphic fragments, tested in individuals of cultivars IPR 116 and CATI AL-100 of the radish (Raphanus sativus L. var. oleiferus Metzg)

\begin{tabular}{|c|c|c|c|}
\hline Sequence name & Sequence 5'- 3' & Number of amplified products & Number of polymorphic fragments \\
\hline OPK 04 & CCGCCCAAAC & 10 & 0 \\
\hline OPK 10 & GTGCAACGTG & 3 & 1 \\
\hline OPK 14 & CCCGCTACAC & 11 & 1 \\
\hline OPK 17 & CCCAGCTGTG & 9 & 0 \\
\hline OPL 04 & GACTGCACAC & 6 & 3 \\
\hline OPL 05 & ACGCAGGCAC & 10 & 3 \\
\hline OPL 07 & AGGCGGGAAC & 10 & 3 \\
\hline OPL 15 & AAGAGAGGGG & 3 & 1 \\
\hline OPL 18 & ACCACCCACC & 5 & 1 \\
\hline OPL 19 & GAGTGGTGAC & 5 & 3 \\
\hline OPM 04 & GGAGGTTGTC & 3 & 1 \\
\hline OPM 06 & CTGGGCAACT & 10 & 3 \\
\hline OPM 07 & CCGTGACTCA & 14 & 5 \\
\hline OPM 09 & CCTTCAGGCA & 1 & 1 \\
\hline OPM 15 & GACCTACCAC & 0 & 0 \\
\hline OPM 19 & CCTTCAGGCA & 7 & 0 \\
\hline OPN 01 & CTCACGTTGG & 1 & 0 \\
\hline OPN 05 & ACTGAACGCC & 5 & 0 \\
\hline OPN 12 & CACAGACACC & 10 & 5 \\
\hline OPN 16 & AAGCGACCTG & 13 & 3 \\
\hline OPN 18 & GGTGAGGTCA & 0 & 0 \\
\hline OPN 19 & GTCCGTACTG & 5 & 1 \\
\hline OPO 05 & CCCAGTCACT & 4 & 1 \\
\hline OPO 06 & TCGGCGGTTC & 7 & 3 \\
\hline OPO 12 & CAGTGCTGTG & 5 & 3 \\
\hline OPO 15 & TGGCGTCCTT & 2 & 1 \\
\hline OPO 19 & GGTGCACGTT & 1 & 0 \\
\hline OPO 20 & ACACACGCTG & 10 & 6 \\
\hline S 25 & AGGGGTCTTG & 5 & 2 \\
\hline S 27 & GAAACGGGTG & 2 & 1 \\
\hline S31 & CAATCGCCGT & 12 & 3 \\
\hline S 36 & AGCCAGCGAA & 3 & 2 \\
\hline S 38 & AGGTGACCGT & 4 & 1 \\
\hline S 297 & GACGTGGTGA & 5 & 2 \\
\hline S 300 & AGCCGTGGAA & 7 & 3 \\
\hline S 333 & GACTAAGCCC & 4 & 0 \\
\hline S 499 & ССССCTATCA & 5 & 0 \\
\hline
\end{tabular}


Table 3 - Ratio of the number of amplified ISSR products for each oligonucleotide, with their respective numbers of polymorphic fragments, tested in 116 individuals of cultivars IPR and CATI AL-100 of the radish (Raphanus sativus L. var. oleiferus Metzg)

\begin{tabular}{lccc}
\hline Sequence name & Sequence 5' - 3' & Number of amplified products & Number of polymorphic fragments \\
\hline UBC 808 & AGA GAG AGA GAG AGA GC & 07 & 04 \\
UBC 810 & GAG AGA GAG AGA GAG AT & 08 & 06 \\
UBC 812 & GAG AGA GAG AGA GAG AA & 09 & 04 \\
UBC 820 & GTG TGT GTG TGT GTG TC & 00 & 00 \\
UBC 827 & ACA CAC ACA CAC ACA CG & 07 & 04 \\
UBC 834 & AGA GAG AGA GAG AGA GYT & 10 & 06 \\
UBC 848 & CAC ACA CAC ACA CAC ARG & 12 & 07 \\
UBC 851 & GTG TGT GTG TGT GTG TYG & 07 & 02 \\
UBC 858 & TGT GTG TGT GTG TGT GRT & 01 & 00 \\
UBC 878 & GAA TGG ATG GAT GGA & 04 & 03 \\
\hline
\end{tabular}

The similarity index calculated by the Jaccard coefficient was 0.45 , lower than that calculated by RAPD (0.71). The percentage of polymorphic bands with ISSR was higher (53.4\%) than with RAPD (29.5\%), as was the average for polymorphic bands, that is, the ISSR technique produced on average a greater number of informative bands. ISSR markers were considered more efficient than RAPD by Fernandez, Figueiras and Benito (2002) in the identification of polymorphism and reproducibility of the amplification.

This study demonstrates that RAPD and ISSR biochemical and molecular markers are effective and promising when differentiating cultivars of the radish, making it possible to estimate and identify the genetic variability among the cultivars.

\section{CONCLUSION}

1. The glutamate oxaloacetate, malate dehydrogenase, esterase and superoxide dismutase enzyme systems made it possible to distinguish between the cultivars IPR 116 and CATI AL-1000 of the radish;

2. The RAPD and ISSR markers make it possible to estimate and identify specific genetic patterns for the radish cultivars CATI AL-1000 and IPR 116.

\section{ACKNOWLEDGEMENT}

The authors wish to thank the Instituto Agronômico do Paraná (IAPAR) and the Coordenadoria de Assistência Técnica Integral of the state of São Paulo (CATI) for donating seeds. The authors also thank FAPEMIG and CAPES for their financial support.

\section{REFERENCES}

ABDALLA, A. L. et al. Utilização de subprodutos da indústria de biodiesel na alimentação de ruminantes. Revista Brasileira de Zootecnia, v. 37, p. 260-268, 2008. Número Especial.

ALFENAS, A. C. et al. Eletroforese e marcadores bioquímicos em plantas e microrganismos. 2. ed. Viçosa: UFV, 2006. 627 p.

AREIAS, R. G. B. M. et al. Similaridade genética de variedades crioulas de arroz, em função da morfologia, marcadores RAPD e acúmulo de proteína nos grãos. Bragantia, v. 65, n. 1, p. 19-28, 2006.

ASTARINI, A. I. et al. Fingerprinting of cauliflower cultivars using RAPD markers. Australian Journal of Agricultural Research, v. 55, n. 2, p. 117-124, 2004.

BORÉM, A.; MIRANDA, G. V. Melhoramento de plantas. 6. ed. Viçosa: UFV, 2013. 523 p.

BYRNE, D. H.; LITTLETON, T. G. Electrophoretic characterization of diploid plums of southeastern United States. Journal American Society Horticulturae Science, v. 113 , n. 6, p. 918-924, 1988.

CRUSCIOL, C. A. C. et al. Persistência de palhada e liberação de nutrientes do nabo forrageiro no plantio direto. Pesquisa Agropecuária Brasileira, v. 40, n. 2, p. 161-168, 2005.

DERPSCH, R.; CALEGARI, A. Plantas para adubação verde de inverno. Londrina: Iapar, 1992. $80 \mathrm{p}$.

DOYLE, J. J.; DOYLE, J. L. Isolation of plant DNA from fresh tissue. Focus, v. 12, n. 1, p. 13-15, 1990.

FERNANDEZ, M. E.; FIGUEIRAS, A. M.; BENITO, C. The use of ISSR and RAPD markers for detecting DNA polymorphism, genotype identification and genetic diversity among barley cultivars with known origin. Theoretical and Applied Genetics, v. 104, n. 5, p. 845-851, 2002.

FERREIRA, C. A. et al. Identificação de cultivares de Gladiolus sp. por meio de marcadores genético-bioquímicos e 
de RAPD. Revista Brasileira de Horticultura Ornamental, v. 15, n. 2 , p. $115-126,2009$.

FERREIRA, D. F. SISVAR - Sistema de análise de variância para dados balanceados: programa de análises estatísticas e planejamento de experimentos, versão 4.1. Lavras: UFLA, 2000 .

FERREIRA, M. E.; GRATTAPAGLIA, D. Introdução ao uso de marcadores moleculares em análise genética. 3. ed. Brasília: Embrapa-CENARGEN, 1998. 220 p.

HU, J.; QUIROS, C. F. Identification of broccoli and cauliflower cultivars with RAPD markers. Plant Cell Reports, v. 10, n. 10, p. 505-511, 1991.

INTERNATIONAL SEED TESTING ASSOCIATION. Rules for seed testing. Zürich: ISTA, 1996. $44 \mathrm{p}$.

KONG, Q. et al. Genetic Diversity of Radish (Raphanus sativus L.) Germplasm resources revealed by AFLP and RAPD markers. Plant Molecular Biology Reporter, v. 29, n. 1, p. 217-223, 2011.

LIMA, M. R. et al. Caracterização de cultivares de pessegueiro e nectarineira por marcadores moleculares. Pesquisa Agropecuária Brasileira, v. 38, n. 3, p. 349-355, 2003.

LIU, L. et al. Genetic diversity analysis of radish germplasm with RAPD, AFLP and SRAP markers. Acta Horticulturae, v. 1, n. 760, p. 125-130, 2007.

LIU, L. et al. DNA fingerprinting and genetic diversity analysis of late-bolting radish cultivars with RAPD, ISSR and SRAP markers. Scientia Horticulturae, v. 116, n. 3, p. 240-247, 2008.

MADHOU, P. et al. Genetic variation in populations of Western Australian wild radish. Australian Journal of Agricultural Research, v. 56, n. 10, p. 1079-1087, 2005.

MAGUIRE, J. D. Speed of germination: aid in selection and evaluation for seedling emergence and vigor. Crop Science, v. 2, n. 2, p. 176-177, 1962.

MALONE, G. et al. Expressão diferencial de isoenzimas durante o processo de germinação de sementes de arroz em grandes profundidades de semeadura. Revista Brasileira de Sementes, v. 29 , n. 1 , p. $61-67,2007$

MARTINS, C. C. et al. Isoenzimas na diferenciação de sementes de três espécies do gênero Euterpe. Revista Árvore, v. 31, n. 1, p. 51-57, 2007.

MENEZES, M. et al. Identificação de cultivares de milho, feijão, algodão e soja por meio de enzimas e proteínas resistentes ao calor. Revista Brasileira de Sementes, v. 30, n. 2, p. 111-122, 2008.

MOHAMED, A. H. Molecular systematic of some brassicaceae taxa in egypt based on electrophoretic isoenzymes pattern and RAPD markers. Australian Journal of Basic and Applied Sciences, v. 3, n. 3, p. 1499-1511, 2009.
MUMINOVIC, J. et al. Genetic structure and diversity among radish varieties as inferred from AFLP and ISSR analyses. Journal of the American Society for Horticultural Science, v. 130, n. 1, p. 79-87, 2005.

NERY, M. C.; CARVALHO, M. L. M.; FRAGA, A. C. Adequação do teste de germinação para sementes de nabo forrageiro. Revista Brasileira de Sementes, v. 31, n. 2, p. 177-187, 2009.

PERVAIZ, Z.H. et al. Assessment of genetic variability in rice (Oryza sativa L.) germplasm from Pakistan using RAPD markers. Pakistan Journal of Botany, v. 42, n.5, p. 3369-3376, 2010.

PRADHAN, A.; YAN, G.; PLUMMER, J. A. Development of DNA fingerprinting keys for the identification of radish cultivars. Australian Journal Experimental Agriculture, v. 44, n. 1, p. 95-102, 2004.

RABBANI, M. A. et al. Genetic variation in radish (Raphanus sativus L.) germplasm from Pakistan using morphological traist and RAPDs. Genetic Resources and Crop Evolution, v. 45, n. 4 , p. $307-316,1998$.

ROHLF, F. J. NTSYS-pc: numerical taxonomy and multivariate analysis system. version 2.1. New York: Exeter Software, 2000. 98 p.

SANGUINETTI, C. J.; DIAS NETO, E.; SIMPSON, A. J. G. Rapid silver staining and recovery of PCR products separated on polyacrylamide gels. Biotechniques, v. 17, n. 5, p. 914-921, 1994.

SCANDALIOS, J. G. Genetic control of multiple molecular forms of enzymes in plants: a review. Biochemical Genetics, v. 3, n. 1, p. 37-39, 1969.

SHIRASAWA, K. et al. An EST-SSR linkage map of raphanus sativus and comparative genomics of the Brassicaceae. DNA Research, v. 18, n. 4, p. 221-232, 2011.

SOUZA, A. D. V. et al. Caracterização química de sementes e tortas de pinhão-manso, nabo-forrageiro e crambe. Pesquisa Agropecuária Brasileira, v. 44, n. 10, p. 1328-1335, 2009.

TAGIZAD, A. et al. A comparative analysis of ISSR and RAPD markers for studying genetic diversity in Iranian pistachio cultivars. Iranian Journal of Genetics and Plant Breeding, v. 1, n. 1, p. 9-19, 2010.

TRIPATHI, N. et al. Assessment of genetic variations among highly endangered medicinal plant Bacopa monnieri (L.) from Central India using RAPD and ISSR analysis. Biotech, v. 2, n. 4, p. 327-336, 2012.

VIEIRA, E. S. N. et al. Caracterização de cultivares de soja por descritores morfológicos e marcadores bioquímicos de proteínas e isoenzimas. Revista Brasileira de Sementes, v. 31, n. 1, p. 86-94, 2009.

WEEDEN, N. F.; WENDEL, J. F. Genetics of plant isozymes. In: SOLTIS, D. E.; SOLTIS, P. S. (Ed). Isozymes in plant biology. London: Chapman and Hall, 1990. p. 46-72. 